\title{
Biotic interactions in the rhizosphere in relation to plant and soil nutrient dynamics
}

\author{
J. Larsen $^{1 *}$, P. Jaramillo-López ${ }^{1}$, M. Nájera-Rincon ${ }^{1,2}$ and C.E. Gonzaléz-Esquivel ${ }^{1}$ \\ ${ }^{1}$ Instituto de Investigaciones en Ecosistemas y Sustentabilidad, Universidad Nacional Autónoma de México, \\ Antigua Carretera a Pátzcuaro No. 8701, C.P. 58190 Morelia, Michoacán, México. ${ }^{2}$ Campo Experimental \\ Uruapan, Instituto Nacional de Investigaciones Agropecuarias y Forestales, Av. Latinoamericana No. 1101, \\ Colonia Revolución, C.P. 60150, Uruapan. Michoacán, México. \\ "Corresponding author: jlarsen@cieco.unam.mx
}

\begin{abstract}
The rhizosphere is the interface between roots and the soil where nutrient absorption for plant growth in agroecosystems is facilitated. An abundant and diverse rhizosphere biome is involved in biogeochemical processes, including bacteria, fungi and soil fauna, driving soil C, N and P dynamics. Plant carbon photosynthates allocated to the root and rhizosphere are priming microbial activities important for plant nutrition such as organic matter decomposition, $\mathrm{P}$ solubilization, $\mathrm{N}$ fixation, mycorrhizal nutrient transport and biocontrol of root pests. While substantial information is available on the role of individual groups of the rhizosphere microbiome in biogeochemical processes, less attention has been given to the interactions between different beneficial rhizosphere microorganisms. Also, interactions between soil fauna and rhizosphere microorganisms still remain relatively unexplored. In order to improve our knowledge on the role of the rhizosphere in $\mathrm{C}, \mathrm{N}$ and $\mathrm{P}$ biogeochemical processes a more holistic and functional approach is required. In this review, state of the art information on the role of biotic interactions in the rhizosphere on $\mathrm{C}, \mathrm{N}$ and $\mathrm{P}$ biogeochemical processes relevant for plant nutrition in agroecosystems is presented.
\end{abstract}

Keywords: Biogeochemistry, rhizosphere microbiome, mycorrhizosphere, root health, soil fauna

\section{Introduction}

Plant production relies on biogeochemical is especially true for $\mathrm{C}, \mathrm{N}$ and $\mathrm{P}$ biogeochemical processes, which are mainly driven by biotic factors. However, abiotic processes such as weathering to some extent, also contribute with the release of essential nutrients for plant growth. This processes, which are pivotal for plant production in agroecosystems (Drinkwater and Snapp, 2007). The rhizosphere, which is defined as "the field of action or influence of a root" (Lynch and Leij, 2012), is 
the interface between the plant and the soil, where plants acquire nutrients facilitated by biogeochemical processes. Carbon flows from the plant to the soil ecosystem as simple organic compounds providing the necessary food basis for the corresponding microbiological processes that are vital for soil ecosystem functioning (Jones et al., 2009). In this way, photosynthates flow rapidly from the plant to the soil feeding the rhizosphere microbiome, which in turn provides food for microbial grazers and their predators (Fitter et al., 2005). The rhizosphere microbiome is abundant and diverse with bacteria and fungi being the key players in relation to plant and soil C, N and P dynamics (Lynch, 1987; Philippot et al., 2013). However, bacterial and fungal grazers (protozoa, nematodes, mites and collembolans) and grazer predators (predator mites and nematodes) are also important regulators of biogeochemical processes (Bonkowski, 2004; Coleman, 2008). Both plant beneficial microorganisms (plant growth promoters and biocontrol agents) and pests (root pathogens and root feeding insects) are common inhabitants of the rhizosphere (Whipps, 2001; Morgan et al., 2005; Raaijmakers et al., 2009), all affecting $C, N$ and $P$ biogeochemical processes in the soil. Functional traits of the beneficial rhizosphere microbiome in relation to plant nutrition and health include organic matter decomposition, $\mathrm{P}$ solubilization and transport, $\mathrm{N}$ fixation and biocontrol of root pests (Philippot et al., 2013).

Plant-microbe-soil interactions strongly modulate $\mathrm{C}, \mathrm{N}$ and $\mathrm{P}$ dynamics in the soil. However, the conventional rhizosphere concept focuses mainly on root-microbe interactions in relation to plant nutrition (mycorrhiza and rhizobium) and microbe-microbe interactions in relation to plant health (biocontrol of root pathogens). Less information is available on the interactions between beneficial rhizosphere microorganisms from different functional groups and interactions between soil fauna and rhizosphere microorganisms still remains relatively unexplored.
In order to improve our knowledge on the role of the rhizosphere in $\mathrm{C}, \mathrm{N}$ and $\mathrm{P}$ biogeochemical processes a more holistic and functional approach is required. Hence, the main objective of this review is to provide state of the art information on the role of biotic interactions in the rhizosphere on $\mathrm{C}, \mathrm{N}$ and $\mathrm{P}$ biogeochemical processes relevant for plant nutrition in agroecosystems.

\section{Biogeochemical processes in the mycorrhizosphere}

Most plants naturally form mycorrhizae with fungi from the phylum Glomeromycota (Smith and Read, 2008). This common mycorrhizal association is characterized by the bidirectional nutrient exchange, where the fungus receives sugar from its host plant and in return provides important ecosystem services for plant production, which improve both plant nutrition and health (Gianinazzi et al., 2010). Arbuscular mycorrhizae (AM) are known to strongly affect rhizosphere microbial communities, as presented in several reviews (Linderman, 1988; Barea et al., 2002; Johansson et al., 2004; Artursson et al., 2006; Bending et al., 2006), which is why the term mycorrhizosphere was employed to emphasize the vital importance of mycorrhizal associations in root function (Linderman, 1988).

\subsection{The role of AM fungi in the C cycle}

Despite the biotrophic nature of AM fungi, acceleration of organic matter decomposition has been linked to these microorganisms (Hodge et al., 2001). Improved growth of AM fungi in patches that are rich in organic matter has been reported (Albertsen et al. 2006; Ravnskov et al., 1999, Gavito and Olsson, 2003) and growth of AM fungi has been shown to be stimulated by the decomposition of organic compounds (Gryndler et al., 2008). Acceleration of organic matter decomposition by AM fungi could lead to an increased release of $\mathrm{CO}_{2}$ from the soil through microbial respiration (Cheng et al., 2012), but this may 
be counteracted by the increased photosynthetic activity and therefore $\mathrm{CO}_{2}$ uptake by plants (Hughes et al., 2008). Furthermore, since a substantial part of the photosynthates from the host plant are invested in the formation of AM fungal biomass, both in terms of root colonization and mycelial network in the soil, AM fungi have been suggested to be important in carbon sequestration in the soil, hence mitigating $\mathrm{CO}_{2}$ emissions from agricultural soils (Solaiman, 2014). Though information on the importance of $\mathrm{AM}$ fungi in the $\mathrm{C}$ cycle is being generated in various areas of interest, especially regarding climate change (Fitter et al., 2000) a more thorough analyses of the role of AM fungi in the $\mathrm{C}$ cycle could provide missing information required to develop a more solid model on this matter.

\subsection{The role of AM fungi in the $N$ cycle}

Regarding the importance of AM fungi on the $\mathrm{N}$ cycle in agroecosystems, recently more focus has been directed to this issue providing new information especially in relation to $\mathrm{N}$ mineralization and $\mathrm{N}$ denitrification (Hodge and Storer, 2015). In general, it is well established that AM fungi can transport $\mathrm{N}$ as $\mathrm{NH}_{4}^{+}$to the host plant (Johansen et al, 1992; Hawkins et al., 2000; Hodge et al., 2001; Atul-Nayyar et al., 2009). Only recently a more complete model of the importance of AM fungi in $\mathrm{N}$ biogeochemical processes has been addressed (Veresoglou et al., 2012; Hodge and Storer, 2015), which suggests that arbuscular mycorrhizae reduce $\mathrm{N}$ loss from the soil in terms of leaching and denitrification (Cavagnaro et al., 2012).

\subsection{The role of AM fungi in the P cycle}

The importance of AM fungi in biogeochemical processes has focused mainly on $\mathrm{P}$ since these fungi are known to transport immobile $\mathrm{P}$ from the soil to the host plant (Jeffries and Barea, 1994). However, it is still unclear whether AM fungi can solubilize organic (Joner et al., 2000) and mineral forms of P (Bagyaraj et al., 2015), but $P$ solubilization is a well-known trait of some bacteria associated with AM fungi (Cruz and Ishii, 2012; Wang et al., 2012). Thus it is logical to assume that at least some of the $\mathrm{P}$ transported by the AM fungi to the host plant may be derived from $\mathrm{P}$, which is solubilized by associated microorganisms (Azcon et al., 1976; Souchie et al., 2006; Osorio and Habte, 2013; Zhang et al., 2014). Though synergistic interactions between AM fungi and other soil microorganisms in relation to $\mathrm{P}$ uptake from organic and mineral $\mathrm{P}$ sources has now been studied for decades, more detailed information needs to be obtained in order to reveal the role of AM fungi and other soil microorganisms in this matter.

\section{Microbial interactions in the mycorrhizophere}

Microbial interactions in the rhizosphere have been extensively examined especially in terms of plant health and nutrition (Whipps, 2001; Morgan et al., 2005; Lambers et al., 2009; Ryan et al., 2009; Larsen et al., 2015; Phillipot et al., 2015). However, knowledge on how biotic interactions in the rhizosphere affect $\mathrm{C}, \mathrm{N}$ and $\mathrm{P}$ plant-soil dynamics is still limited. Moreover, information on functional aspects of microbial interactions has been largely ignored. In most cases, biotic interactions in the rhizosphere have been examined in terms of biomass quantification of the biota in question and to a lesser extent in functional terms.

In this regard, arbuscular mycorrhizae play a key role in bridging the gap in the plant-soil interface with an extensive external mycelial network (Jakobsen et al., 1994).

\subsection{The mycorrhizosphere microbiome}

AM fungi not only associate with plant roots, but also establish close associations with bacteria in the AM 
fungus-mycosphere and may include spores (Xavier and Germida, 2003b; Bharadwaj et al., 2008; Cruz and Ishii, 2012) and external mycelia (Mansfeld-Giese et al., 2002). Mycorrhiza-associated bacteria seem to be thriving from AM fungal exudates (Toljander et al., 2007). Even more intimate associations between endosymbiotic bacteria and the AM fungus Gigaspora margarita (Bianciotto et al., 1996) demonstrate the very complex tripartite symbiosis between plants, AM fungi and associated bacteria. Known functional traits of AM fungus associated bacteria include $\mathrm{N}$ fixation, $\mathrm{P}$ solubilization and root pathogen biocotrol (Bonfante and Anca, 2005). Hence mycorrhiza-associated bacteria may facilitate $\mathrm{N}$ and $\mathrm{P}$ nutrition for both plant and fungal partners in mycorrhizal associations as well as protecting arbuscular mycorrhizae against root pests.

AM fungi have been reported to shape the rhizosphere microbiome both in qualitative and quantitative terms (Linderman, 1988; Barea et al., 2002; Bending et al., 2006). This is most likely achieved through quantitative and qualitative changes in root exudates (Jones et al., 2004). AM fungi differentially affect microbial communities both in the mycorrhizosphere and in the AM fungal hyphosphere (Welc et al., 2010), which could be closely related to changes in exudates (Toljander et al., 2007). In most cases, reduced microbial biomass and activity in the mycorrizosphere compared to that of the non-mycorrhizal rhizosphere have been reported (Ravnskov et al., 2006; Larsen et al., 2009) and different AM fungal species differentially affect rhizosphere microbial communities. In this way the nutrient resources for the mycorrhizal symbiosis are maintained in a tight connection minimizing microbial $\mathrm{N}$ and $\mathrm{P}$ immobilization.

\subsection{Organic matter decomposition}

Though mycorrhizal associations may suppress other microbiota, this does not seem to affect their activity in terms of organic matter decomposition, which on the contrary, has been shown to be accelerated by arbuscular mycorrhizae (Hodge et al., 2001; Ravnskov et al., 2006; Cheng et al., 2012). Dual inoculation with the AM fungus Glomus intraradices and the saprotrophic fungus Clonostachys rosea counteracted growth depressions in tomato plants grown in soil amended with organic matter despite of mutual inhibition between these fungi (Ravnskov et al., 2006). Interestingly, both fungi reduced the microbial biomass in the rhizosphere and changed the microbial community perhaps improving the energy and nutrient use efficiency in question. Despite of the biotrophic nature of AM fungi, they seem to thrive well in organic matter patches (Ravnskov et al., 1999; Gavito and Olsson, 2003), which may be facilitated by their saprotrophic microbial associations, but this remains to be demonstrated. In general, more attention should be given to better address the underlying mechanisms for these microbial interactions in relation to organic matter decomposition.

\subsection{AM hyphal P transport}

Since AM fungi promote host plant $\mathrm{P}$ nutrition via AM hyphal $\mathrm{P}$ transport from the soil to the plant it is important to know how other soil biota affect this key function of AM fungi. $\mathrm{P}$ isotope tracer technology combined with the use of compartmented growth systems with rootfree compartments (Jakobsen, 1994) has improved the knowledge on the interactions between AM fungi and other soil biota. Employing the isotope method platform developed by Jakobsen (1994), effects of microbial the biocontrol agents (Trichoderma harzianum, Green et al., 1999; Burkholderia cepacia, Ravnskov et al., 2002; Pseudomonas flourescens, Ravnskov et al., 1999), plant growth promoters (Aspergillus niger, Medina et al., 2006), root pathogens (Fusarium culmorum, Larsen et al., 1998) and soil animals (Collembola, Folsomia candida, Larsen and Jakobsen, 1996) on AM hyphal P transport have been 
examined. Surprisingly, the general conclusions from these experiments suggest that AM hyphal $\mathrm{P}$ transport is relatively unaffected by other soil microorganisms. Most likely the ecological advantage of AM fungi receiving energy directly from its host plant makes these fungi superior soil competitors in comparison to saprotrophic rhizosphere inhabiting microorganisms. In addition, most studies on interactions between AM fungi and mycophagous soil animals suggest that AM fungi are less palatable as a food source than other filamentous fungi (Larsen et al., 2008), which explains why limited effects of soil fauna on AM hyphal P transport have been reported (Larsen and Jakobsen, 1996a,b). On the other hand, information on the interactions between soil fauna and other functional groups of microorganisms such as $\mathrm{P}$ solubilizing, $\mathrm{N}$ fixing and biocontrol microorganisms is limited and could be relevant to determine the interactions between soil fauna and microorganisms in terms of biogeochemical processes.

\subsection{Microbial P solubilization}

In relation to plant and soil $\mathrm{P}$ dynamics it is also important to consider microbial $\mathrm{P}$ solubilization and how other rhizosphere microorganisms affect this process. A broad range of bacteria, actinomycetes, filamentous fungi and yeasts have been shown to solubilize different types of minerals as well as organic P (Sharma et al., 2013). On the other hand, the solubilized $\mathrm{P}$ can be immobilized by the same microorganisms that solubilized the $\mathrm{P}$ and/or by other microorganisms while the microbially solubilized $\mathrm{P}$ at first may not be available for plant roots. Again, here the mycorrhizal association most likely plays a crucial role in sequestering the phosphorous from the soil solution and subsequently storing $\mathrm{P}$ as polyphosphate granules in the fungal structures in soil and roots providing the basis for $\mathrm{P}$ and $\mathrm{C}$ interchange between fungal and plant partners in the mycorrhizal association. However, at this point the abovementioned theory is merely a hypothesis that needs to be further addressed. Interestingly, AM fungi have been shown to increase alkaline phosphatase activity in the rhizosphere (Bagyaraj et al., 2015), but little is known about the influence of AM fungi on mineral $\mathrm{P}$ solubilization by other soil organisms.

\subsection{Microbial N fixation}

Biological nitrogen fixation carried out by both symbiotic and free-living rhizospheric bacteria provide substantial amounts of $\mathrm{N}$ to both crops and soil biota in agroecosystems (Franche et al., 2009; $\mathrm{Xu}$ et al., 2012). However, limited information is available on how other soil biota affect this important biogeochemical process. Regarding rhizobial associations between symbiotic nodule-forming bacteria and leguminous crops in general, mycorrhizal plants seem to improve rhizobial $\mathrm{N}$ fixation though the two symbionts are competing for allocation of plant sugar (Javaid, 2010).

Free-living diazotrophic bacteria such as Azospirillum, Burkholderia and Bacillus are known to promote plant growth not only through $\mathrm{N}$ fixation but also by inducing root branching, $\mathrm{P}$ solubilization and biocontrol of root pathogens (Dobbelaere et al., 2003; Vessey, 2003; Lugtenberg and Kamilova, 2009). Information on how other rhizosphere microorganisms affect free-living diazotrophic bacteria is limited and to the best of our knowledge information on the impacts of other soil biota on $\mathrm{N}$ fixation from this group of rhizosphere bacteria is missing.

\section{Root health}

Main root pests include plant pathogens (fungi, oomycetes, protozoa and nematodes) and root-feeding insects, which all obtain their basal energy from the 
root system though in different forms depending on the life strategy of the individual pest. Knowledge of the role of root pests in biogeochemical cycles and C, $\mathrm{N}$ and $\mathrm{P}$ dynamics in soil is limited. In some cases, root disease symptoms especially from oomycete and nematode pathogens can be confused with nutrient and water deficiency because the root system fails to support the plant with sufficient nutrients and water. Root feeding insects cause similar nutrient and water deficiency symptoms since root herbivory damages the root system and thereby its absorptive capacity (Johnson et al., 2013). Another important aspect to consider is that the nutrient absorptive capacity of the plant also depends on the external mycelium of rootinhabiting AM fungi. Root damage will eventually lead to reduced production of external mycelium by AM fungi and thereby reduce the capacity of AM hyphal P transport to the plant. On the other hand, AM fungi have been shown to alleviate plant stress from root pests, which may be related to induction of tolerance related to compensation by improving host plant nutrient and water dynamics (Whipps, 2004; St. Arnaud and Vujanovic, 2007).

\subsection{Nematodes}

Plant parasitic nematodes cause substantial crop losses in most agricultural crops worldwide (Zasada et al., 2008). Root feeding by ectoparasitic nematodes and formation of numerous root galls by endoparasitic nematodes, reduces plant nutrient absorption causing the plant to become stunted or chlorotic (Ellis et al., 2008). Often, this is misdiagnosed as nutrient deficiency by the farmer rather than nematode infestation.

Non-parasitic nematodes are also common in the rhizosphere and an increase in the populations of freeliving species of nematodes can be an indicator of soil health, reflecting improvements on the availability of nutrients, water-holding capacity, soil structure, $\mathrm{pH}$, and buffering capacity (Magdoff, 2001; Widmer et al., 2002). The ubiquitous distribution of nematodes is due to the fact that they have very diverse and specialized feeding habits contributing to soil processes related to nutrient cycling. There is an estimated half a million species of nematodes that feed on a wide range of organisms, including bacteria, fungi, and other nematodes (Strange, 2003). Due to the interactions among nematodes and so many different organisms, they are key players in various food webs at several trophic levels (Ingham et al., 1985). As a result of these interactions, many elements are released in the soil matrix, serving as plant nutrients (Neher, 2001). An estimated $8-19 \%$ of $\mathrm{N}$ mineralization in soils is attributed to the activity of predatory and bacterial feeding nematodes (Beare, 1997).

Addition of soil organic amendments has been shown to enhance the activity of "grazer" nematodes that feed on soil bacteria and fungi (Freckman, 1988; Ferris and Fu et al., 2000; Matute, 2003; Oka, 2010). This frenzy of microbial activity creates ideal conditions for improved nutrient cycling, which in turn benefit root development and plant growth (Hamilton III and Frank, 2001). Akhtar and Malik (2000) reviewed the various roles of organic amendments and how they favor the proliferation of predatory nematodes, sporozoan parasites, and other natural enemies of phytoparasitic nematodes. The application of organic matter to agricultural soils may also have an effect on various components of the soil food web, increasing the propagule density of nematophagous fungi (Venette et al., 1997) and the adhesive network of traps and knobs that allow nematophagous fungi to reduce plant-parasitic nematode populations (Jaffee, 2004). Akhtar and Alam (1993) reviewed the direct or indirect stimulation of biocontrol agents that reduce plantparasitic nematodes. Furthermore, the application of organic amendments that are high in $\mathrm{N}$ may have a 
negative effect on plant-parasitic nematodes because they produce compounds such as ammonia and nitrous acid that have nematicidal properties (Oka, 2010). These properties are enhanced by certain physical and chemical changes such as soil buffering capacity, $\mathrm{pH}$, and organic matter content resulting from the application of organic amendments (Lazarovits, 2001). Amendments such as meat and bone meal have shown promising results in reducing some soilborne diseases, but their efficacy depends on the characteristics of the soil to which the amendments are applied (Tenuta and Lazarovits, 2004). Soils with low organic carbon and to some extent the amount of sand present were very important in ammonia accumulation which in turn resulted in effective control for some of these soilborne diseases (Tenuta and Lazarovits, 2002). Several studies have shown the potential of parasitic and nonparasitic bacteria to control plant-parasitic nematodes (Trudgill et al., 2000; Meyer et al., 2000). Chen et al. (1994) documented that Pasteuria penetrans can act as a biocontrol agent for the suppression of plantparasitic nematodes. Non-parasitic rhizobacteria have the potential of reducing plant-parasitic nematode populations by means of colonizing the roots of the host plant and producing certain compounds that have nematicidal properties (Siddiqui and Mahmood, 1999).

\subsection{Root feeding insects}

Ecology of root herbivores has received little attention, among other reasons because of the inherent difficulty of working with soil dwelling insects. Due to the diversity of taxonomic groups of insects affecting cultivated plants there is little ornoinformationavailableaboutunderground behaviour of some immature stages of certain insects that have been identified as pests (Morón, 2004). Root feeding insects not only cause damage to underground parts of plants, but their activity may also include positive effects on the ecosystem because they stimulate renewal of root systems. This happens because these insects feed on old roots and this promotes the development of secondary root meristem. Additionally, they consume fungal mycelia regulating its growth and taking part in the dispersion and conservation of mycorrhizae (Rabatin and Stinner, 1988). Some root feeding insects not only feed on roots, but also on organic matter, favoring mineralization and recycling of plant nutrients, particularly $\mathrm{N}, \mathrm{S}$, and $\mathrm{P}$, through immobilization, which prevents nutrient losses from leaching (Villalobos, 1994; 1994a). In an experiment to assess the role of soil nutrients as mediators of the interactions between root feeding and leaf insects, Johnson et al. (2009) determined that foliar and root herbivory caused by aphids (Rhopalosiphum padi) and wireworms (Agriotes spp.) respectively, had several interactive effects; generally reversible on plant nutrients. Wireworms caused little impact on the nutritional chemistry when compared to aphids, which were negatively related to the $\mathrm{P}$ content in both leaves and roots. In the short term, wireworms favored aphid population density to increase due to an increase of $\mathrm{S}$ in the soil. However, contrary to previous explanations, root herbivory had little impact on the concentration of foliar amino acids. In contrast, aphids caused a significant increase in the concentration of minerals present in the root, especially $\mathrm{S}$, which could potentially promote the activity of wireworms. Recently, there has been increased interest to investigate the role of root herbivores and how they interact in natural ecosystems and agroecosystems (Johnson and Murray, 2008).

\section{Microbial biocontrol in the rhizosphere}

A broad range of microorganisms including bacteria and fungi carry out biocontrol activities in the rhizophere. Multiple biocontrol modes of action include: parasitism, antagonism, competition for nutrients and space and induction of plant defense (Whipps, 2001). Possible non-target effects of biocontrol agents on other soil 
microorganisms and their functions are largely ignored (Brimner and Boland, 2003), which is hampering a successful integration of these plant beneficial microorganisms in agroecosystems. Several of the microbial biocontrol agents against root pathogens and root feeding insects have also been shown to promote plant growth independently from their biocontrol features. The plant growth promoting effect of the biocontrol agent Trichoderma harzianum (Harman et al., 2004) has been suggested to be based on the production of antagonistic compounds against root pathogens, which also serve as plant hormones, which can increase root growth (Vinale et al., 2008).

The soil is a natural reservoir of insect pathogens. Diverse taxonomic groups of pathogenic microorganisms isolated from a number of soil dwelling pests include: viruses, bacteria, fungi, protozoa and nematodes (Jackson and Glare, 1992). These pathogens are able to infect and cause epidemics at immature and adult insect stages with agricultural significance.

In the soil environment, abiotic factors play a role in the incidence, persistence and spread of entomopathogenic microorganisms and nematodes (Studdert and Kaya, 1990, Ignoffo, 1992). Many of the interactions between pathogenic microorganisms in the rhizosphere and their potential hosts are yet to be determined because the aspects related to their ecology and performance in complex multi-trophic food webs in soils are still unknown. Such is the case of entomopathogenic fungi including Metharizium anisoplidae and Beauveria bassiana, which in addition to infecting insects, may act as plant growth promoters or antagonists of plant diseases (Goettel, 2008; Vega et al., 2008).

\section{Conclusions}

Biotic interactions in the rhizosphere drive biogechemical processes and modulate plant nutrient availability in agroecosystems. However, in order to improve our knowledge on the role of the rhizosphere in $\mathrm{C}, \mathrm{N}$ and $\mathrm{P}$ biogeochemical processes a more holistic and functional approach is required.

\section{Acknowledgements}

This work was supported by the Mexican Research Council for Science and Technology (CONACyT) with grant: SEP CB 179319.

\section{References}

Akhtar, M., Alam, M.M. 1993. Utilization of waste materials in nematode control: a review. Bioresource Technol. 45, 1-7.

Akhtar, M., Malik, A. 2000. Roles of organic soil amendments and soil organisms in the biological control of plant-parasitic nematodes: a review. Bioresource Technol. 74, 35-47.

Albertsen, A., Ravnskov, S., Green, H., Jensen, D.F., Larsen, J. 2006. Interactions between the external mycelium of the mycorrhizal fungus Glomus intraradices and other soil microorganisms as affected by organic matter. Soil Biol. Biochem. 38, 1008-1014.

Artursson, V., Finlay, R. D., Jansson, J. K. 2006. Interactions between arbuscular mycorrhizal fungi and bacteria and their potential for stimulating plant growth. Environ. Microbiol. 8, 1-10.

Asghari, H. R., Cavagnaro, T.R. 2011. Arbuscular mycorrhizas enhance plant interception of leached nutrients. Funct. Plant Biol. 38, 219-226.

Atul-Nayyar, A., Hamel, C., Hanson, K., Germida, J. 2009. The arbuscular mycorrhizal symbiosis links $\mathrm{N}$ mineralization to plant demand. Mycorrhiza. 19, 239-246. 
Azcon, R., Barea, J.M., Hayman, D.S. 1976. Utilization of rock phosphate in alkaline soils by plants inoculated with mycorrhizal fungi and phosphate solubilizing bacteria. Soil Biol. Biochem. 8, 135-138.

Bagyaraj, D.J., Sharma, M.P., Maiti, D. 2015. P Nutrition of crops through arbuscular mycorrhizal fungi. Current Science (In press).

Barea, J.M., Azcon, R., Azcon-Aguilar, C. 2002. Mycorrhizosphere interactions to improve plant fitness and soil quality. A. Van Leeuw. 81, 343351.

Beare, M.H. 1997. Fungal and bacterial pathways of organic matter decomposition and nitrogen mineralization in arable soils. In: L. Brussaard, R. Ferrera-Cerrato (eds). Soil ecology in sustainable agricultural systems. CRC/Lewis Publishers, Boca Raton, FL. Pp: 37-70.

Bending, G.D., Aspray, T.J., Whipps, J.M. 2006. Significance of microbial interactions in the mycorrhizosphere. Adv. Appl. Microbiol. 60, 97-132.

Bharadwaj, D.P., Lundquist, P.O., Persson, P., Alström, S. 2008. Evidence for specificity of cultivable bacteria associated with arbuscular mycorrhizal fungal spores. FEMS Microbiol. Ecol. 65, 310-322.

Bianciotto, V., Bandi, C., Minerdi, D., Sironi, M., Tichy, H.V., Bonfante, P. 1996. An obligately endosymbiotic mycorrhizal fungus itself harbors obligately intracellular bacteria. Appl. Environ. Microbiol. 62, 3005-3010.

Bonfante, P., Anca, I.A. 2005. Plants, Mycorrhizal Fungi, and Bacteria: A Network of Interactions. Annu. Rev. Microbiol. 63, 363-83.

Bonkowski, M. 2004. Protozoa and plant growth: the microbial loop in soil revisited New Phytol. 162, 617-631.
Brimner, T.A., Boland, G.J. 2003. A review of the non-target effects of fungi used to biologically control plant diseases. Agr. Ecosyst. Environ. 100, 3-16.

Cavagnaro, T., Barrios-Masias, F., Jackson, L. 2012. Arbuscular mycorrhizas and their role in plant growth, nitrogen interception and soil gas efflux in an organic production system. Plant Soil. 35, 1-14.

Cheng, L., Booker, F.L., Tu, C., Burkey, K. O., Zhou, L., Shew, H. D., Rufty, T. W., Hu, S. 2012. Arbuscular mycorrhizal fungi increase organic carbon decomposition under elevated $\mathrm{CO}_{2}$. Science. 337, 1084-1087.

Chen, S., Dickson, D.W., Whitty, E.B. 1994. Response of Meloidogyne spp. to Pasteuria penetrans, Fungi, and Cultural Practices in Tobacco. Supplement J. Nematol. 26, 620-625.

Clarholm, M. 1985. Interactions of bacteria, protozoa and plants leading to mineralization of soil nitrogen. Soil Biol. Biochem. 17, 181-187.

Coleman, D.C., 2008. From peds to paradoxes: Linkages between soil biota and their influences on ecological processes. Soil Biol. Biochem. 40, 271-289.

Cruz, A.F., Ishii, T. 2012. Arbuscular mycorrhizal fungal spores host bacteria that affect nutrient biodynamics and biocontrol of soil-borne plant pathogens. Biology Open. 1, 52-57.

Dobbelaere, S.,J. Vanderleyden, Y. Okon. 2003. Plant growth-promoting effects of diazotrophs in the rhizosphere. Crit. Rev. Plant Sci. 22, 107-149.

Drinkwater, L.E., Snapp, S.S. 2007. Nutrients in agroecosystems: Rethinking the management paradigm. Adv. Agron. 92, 163-186.

Ellis, S.D., Boehm, M.J., Rhodes, L.H. 2008. Nematode diseases of plants. Extension Fact Sheet from the Department of Agriculture and 
Natural Resources. The Ohio State University, USA. Pp. 1-3

Ferris, H., Matute, M.M. 2003. Structural and functional succession in the nematode fauna of a soil food web. Appl. Soil Ecol. 23, 93-110.

Fitter, A.H., Heinemeyer, A., Staddon, P.L. 2000. The impact of elevated $\mathrm{CO}_{2}$ and global climate change on arbuscular mycorrhizas: a mycocentric approach. New Phytol. 147, 179-187

Fitter, A.H., Gilligan, C.A., Hollingworth, K., et al. 2005. Biodiversity and ecosystem function in soil. Funct. Ecol. 19, 369-377.

Freckman, D.W. 1988. Bacterivorous nematodes and organic-matter decomposition. Agr. Ecosyst. Environ. 24, 195-217.

Franche, C., Lindström, K., Elmerich, C. 2009. Nitrogen-fixing bacteria associated with leguminous and non-leguminous plants. Plant Soil. 321, 35-59.

Fu, S., Coleman, D.C., Hendrix, P.F., Crossley Jr., D. A. 2000. Responses of trophic groups of soil nematodes to residue application under conventional tillage and no-till regimes. Soil Biol. Biochem. 32, 1731-1741.

Gavito, M.E., Olsson, P.A. 2003. Allocation of plant carbon to foraging and storage in arbuscular mycorrhizal fungi. FEMS Microbiol. Ecol. 45, 181-187.

Gianinazzi, S., Gollotte, A., Binet, M.N., van Tuinen, D., Redecker, D., Wipf, D. 2010. Agroecology: the key role of arbuscular mycorrhizas in ecosystem services. Mycorrhiza. 20, 519-530.

Goettel, M.S. 2008. Are entomopathogenic fungi only entomopathogens?: A preamble. J. Invertebr. Pathol. 98, 255.

Green, H., Larsen, J., Olsson, P.A., Jensen, D.F., Jakobsen, I. 1999. Suppression of the biocontrol agent Trichoderma harzianum by mycelium of the arbuscular mycorrhizal fungus Glomus intraradices in root-free soil. Appl. Environ. Microbiol. 65, 1428-1434.

Gryndler, M., Hršelová, H., Cajthaml, T., Havránková, M., Řezáčová, V., Gryndlerová, H., Larsen, J. 2008. Influence of soil organic matter decomposition on arbuscular mycorrhizal fungi in terms of asymbiotic hyphal growth and root colonization. Mycorrhiza. 19, 255-266.

Harman, E.G., Howell, C.R., Viterbo, A., Chet, I., Lorito, M. 2004. Trichoderma species opportunistic, avirulent plant symbionts. Nat. Rev. Microbiol. 2,43-56.

Hamilton III, E.W., Frank, D.A. 2001. Can plants stimulate soil microbes and their own nutrient supply?. Evidence from a grazing tolerant grass. Ecology. 82, 2397-2402.

Hawkins, H. J., Johansen, A., George, E. 2000. Uptake and transport of organic and inorganic nitrogen by arbuscular mycorrhizal fungi. Plant Soil. 226, 275-285.

Hodge, A., Fitter, A.H. 2010. Substantial nitrogen acquisition by arbuscular mycorrhizal fungi from organic material has implications for $\mathrm{N}$ cycling. P.Natl. Acad. Sci. USA 107, 13754-13759.

Hodge, A., Storer, K. 2015. Arbuscular mycorrhiza and nitrogen: implications for individual plants through to ecosystems. Plant Soil. 386, 1-19.

Hodge, A., Campbell, C.D., Fitter, A.H. 2001 An arbuscular mycorrhizal fungus accelerates decomposition and acquires nitrogen directly from organic material. Nature. 413, 297-299.

Hughes, J.K., Hodge, A., Fitter, A.H., Atkin, O.K. 2008. Mycorrhizal respiration: implications for global scaling relationships. Trends Plant Sci. 13, 583-588.

Ignoffo, C.M. 1992. Environmental factors affecting persistence of entomopathogens. Fla. Entomol. 75, 516-525. 
Ingham, R. E., Trofymow, J.A., Ingham, E.R., Coleman, D.C. 1985. Interactions of bacteria, fungi, and their nematode grazers: effects on nutrient cycling and plant growth. Ecol. Monogr. 55, 119-140.

Jackson, T., Glare, T.R. 1992. Use of Pathogens in Scarab Pest Management. Andover: Intercept.

Jaffee, B.A. 2004. Do organic amendments enhance the nematode-trapping fungi Dactylellina haptotyla and Arthrobotrys oligospora. J. Nematol. 36, 267-275.

Jakobsen, I., Joner, E., Larsen, J. 1994. Hyphal P transport a keystone to mycorrhizal functioning. In: Gianinazzi \& Schüepp (eds), Mycorrhizae in sustainable agriculture. pp 133-146.

Jakobsen, I. 1994. Research approaches to study the functioning of vesicular-arbuscular mycorrhizas in the field. Plant Soil. 159, 141-147.

Javaid, A. 2010.Javaid, A Role of Arbuscular Mycorrhizal Fungi in Nitrogen Fixation in Legume. Microbes for legume improvement, pp. 409-426. 2010.

Jeffries, P., Barea, J.M. 1994. Biogeochemical cycling and arbuscular mycorrhizas in the sustainability of plant-soil systems. In: Impact of Arbuscular Mycorrhizas on Sustainable Agriculture and Natural Ecosystems. ALS Advances in Life Sciences 1994, pp. 101-115 Springer.

Johansen, A., Jakobsen, I., Jensen, E.S. 1992. Hyphal transport of ${ }^{15} \mathrm{~N}$-labelled nitrogen by a vesiculararbuscular mycorrhizal fungus and its depletion of inorganic soil N. New Phytol. 122, 281-288.

Johansson, J.F., Paul, L.R., Finlay, R.D. 2004. Microbial interactions in the mycorrhizosphere and their significance for sustainable agriculture. FEMS Microbiol. Ecol. 48, 1-13.

Johnson, S.N., Murray, P.J. 2008. Root feeders: An ecosytsem perspective. CABI, Wallingford, UK.
Johnson, S.N., Hawes, C., Karley, A.J. 2009. Reappraising the role of plant nutrients as mediators of interactions between root- and foliarfeeding insects. Funct. Ecol. 23, 699-706.

Johnson, S.C., Mitchell, C., McNicol, J.W., Thompson, J., Karley, A.J. 2013. Downstairs drivers - root herbivores shape communities of above-ground herbivores and natural enemies via changes in plant nutrients. J. Anim. Ecol. 82, 1021-1030.

Joner, E.J., van Arle, I. M., Vosatka, M. 2000. Phosphatase activity of extra-radical arbuscular mycorrhizal hyphae: A review. Plant Soil. 226, 199-210.

Jones, D.L., Hodge, A., Kuzyakov, Y. 2004. Plant and mycorrhizal regulation of rhizodeposition. New Phytol. 163, 459-480.

Jones, D.L., Nguyen, C., Finlay, R.D. 2009. Carbon flow in the rhizosphere: Carbon trading at the root-soil interface. Plant Soil. 321,25-33.

Lambers, H., Mougel, C., Jaillard, B., Hinsinger, P. 2009. Plant-microbe-soil interactions in the rhizosphere: an evolutionary perspective. Plant Soil. 321, 83-115.

Larsen, J., Najera-Rincon, M., Esquivel Gonzalez, C., Gavito, M.E. 2015. Management of rhizosphere microorganisms in relation to plant nutrition and health. In: Agroecology, Ecosystems and Sustainability. CRC Press.

Larsen, J., Johansen, A., Larsen, S.E., Heckmann, L. H., Jakobsen, I., Krogh, P.H. 2008. Population performance of collembolans feeding on soil fungi from different ecological niches. Soil Biol. Biochem. 40, 360-369.

Larsen, J., Jakobsen, I. 1996a. Interactions between the external mycelium of Glomus caledonium, dry yeast and a mycophagous Collembola. Mycorrhiza. 6, 259-264. 
Larsen, J., Jakobsen, I. 1996b. Effects of a mycophagous Collembola on the symbiosis between Trifolium subterraneum L. and three arbuscular mycorrhizal fungi. New Phytol. 133, 295-302.

Larsen, J., Olsson, P.A., Jakobsen, I. 1998. The use of fatty acid signatures to study mycelial interactions between the arbuscular mycorrhizal fungus Glomus intraradices and the saprothrophic fungus Fusarium culmorum in root free soil. Mycol. Res. 102,1491-1496.

Larsen, J., Cornejo, P., Barea, J.M. 2009. Interactions between the arbuscular mycorrhizal fungus Glomus intraradices and the plant growth promoting rhizobacteria Paenibacillus polymyxa and $P$. macerans in the mycorrhizosphere of Cucumis sativus. Soil Biol.Biochem. 41, 286-292.

Lazarovits, G. 2001. Management of soil-borne plant pathogens with organic soil amendments: a disease control strategy salvaged from the past. C.J. Plant Pathol. 23, 1-7.

Linderman, R.G. 1988. Mycorrhizal interactions with the rhizosphere microflora: the Mycorrhizosphere effect. Phytopathology. 78, 366-370.

Lugtenberg, B., Kamilova, F. 2009. Plant-growthpromoting rhizobacteria. Annu. Rev. Microbiol. $63,541-556$.

Lynch, J.M., de Leij, F. 2012. Rhizosphere. eLS. Lynch, J.M. 1987. The rhizosphere. WileyInterscience. Chichester, UK.

Magdoff, F. 2001. Concept, components, and strategies of soil health in agroecosystems. J.Nematol. 33, 169-172.

Mansfeld-Giese, K.,, Larsen, J., Bødker, L. 2002. Bacterial populations associated with mycelium of the arbuscular mycorrhizal fungus Glomus intraradices. FEMS Microbiol. Ecol. 41, 133140.
Medina, AP., Jakobsen, I., Azcon, R., Vassilev, N., Larsen, J. 2007 Aspergillus niger facilitate hyphal growth and $\mathrm{P}$ uptake of mixed populations of AM fungi grown in sugar beet agrowaste. Soil Biol.Biochem. 39, 485-492

Medina, A., Jakobsen, I., Egsgaard, H. 2011. Sugar beet waste and its component ferulic acid inhibits external mycelium of arbuscular mycorrhizal fungus. Soil Biol. Biochem. 43, 1456-1463.

Meyer, S.L.F., Massoud, S.I., Chitwood, D.J., Roberts, D.P. 2000. Evaluation of Trichoderma virens and Burkholderia cepacia for antagonistic activity against root-knot nematode, Meloidogyne incognita. Nematology. 2, 871-879.

Morgan, J.A.W., Bending, G.D., White, P.J. 2005. Biological costs and benefits to plant-microbe interactions in the rhizosphere. J. Exp. Bot. 56, 1729-1739.

Morón, M.A. 2004. Insetos do solo. In: Salvadori, J.R. Ávila, C.J., Braga da Silva, M.T. (eds.). Pragas de Solo no Brasil. EMBRAPA, Brasil. pp. 41-68

Neher, D.A. 2001. Role of nematodes in soil health and their use as indicators. J. Nematol. 33, 161168.

Oka, Y. 2010. Mechanisms of nematode suppression by organic soil amendments : A review. Appl. Soil Ecol. 44, 101-115.

Osorio, N.W, Habte, M. 2013. Synergistic effect of a phosphate-solubilizing fungus and an arbuscular mycorrhizal fungus on leucaena seedlings in an Oxisol fertilized with rock phosphate. Botany. 91, 274-281

Philippot, L., Raaijmakers, J.M., Lemanceau, P., van der Putten, W.H. 2103. Going back to the roots: the microbial ecology of the rhizosphere. Nat. Rev. Microbiol. 11, 789-799.

Raaijmakers, J.M., Paulitz, T.C., Steinberg, C., Alabouvette, C, Moënne-Loccoz, Y. 2009. 
The rhizosphere: a playground and battlefield for soilborne pathogens and beneficial microorganisms. Plant Soil. 321, 341-361.

Rabatin, S.C., Stinner, B.R. 1988. Indirect effects of interactions between VAM fungi and soilinhabiting invertebrates on plant processes. Agr. Ecosyst. Environ. 24, 135-146.

Ravnskov, S., Jakobsen, I. 1999. Effects of Pseudomonas fluorescens DF57 on growth and $\mathrm{P}$ uptake of two arbuscular mycorrhizal fungi in symbiosis with cucumber. Mycorrhiza. 8, 329334.

Ravnskov, S., Larsen, J., Olsson, P.A., Jakobsen, I. 1999. Effects of different organic substrates on growth and $\mathrm{P}$ uptake of an arbuscular mycorrhizal fungus. New Phytol. 141, 517- 524.

Ravnskov, S., Larsen, J., Jakobsen, I. 2002. Hyphal $\mathrm{P}$ transport of the arbsucular mycorrhizal fungus Glomus intraradices is not affected by the biocontrol bacterium Burkholderia cepacia. Soil Biol.Biochem. 34, 1875-1881.

Ravnskov, S., Jensen, B. Knudsen, I. M. B., Bødker, L., Jensen, D. F., Karlinski, L., Larsen, J. 2006. Soil inoculation with the biocontrol agent Clonostachys rosea and the mycorrhizal fungus Glomus intraradices results in mutual inhibition, plant growth promotion and alteration of soil microbial communities. Soil Biol.Biochem. 38, 3453-3462.

Ryan, P.R., Dessaux, Y., Thomashow, L.S., Weller, D.M. 2009. Rhizosphere engineering and management for sustainable agriculture. Plant Soil. 321, 363-383.

Sharma, S.B., Sayyed, R.Z., Trivedi, M.H., Gobi, T.A. 2013. Phosphate solubilizing microbes: sustainable approach for managing phosphorus deficiency in agricultural soils. SpingerPlus. 2, 587.
Siddiqui, Z.A., Mahmood, I. 1999. Role of bacteria in the management of plant parasitic nematodes: a review. Bioresource Technol. 69, 167-179.

Smith, S.E., Read, D.J. 2008. Mycorrhizal symbiosis, $3^{\text {rd }}$. edn. Academic, London.

Studdert, J. P., Kaya, H. K. 1990. Water potential, temperature, and soil type on the formation of Beauveria bassiana soil colonies. J. Invertebr. Pathol., 56, 380-386

Solaiman, Z.M. 2014. Contribution of arbuscular mycorrhizal fungi to soil carbon sequestration. In: Mycorrhizal fungi: Use in sustainable agriculture and land restoration, Soil Biology series 41, 287296 (eds: Z.M. Solaiman, L.K. Ab bott, A. Varma) Springer verlag Berlin Heidelberg.

Souchie, E.L., Azcón, R., Barea, J.M., SagginJúnior, O.J., Ribeiro da Silva, E. R. 2006. Phosphate solubilization and synergism between P-solubilizing and arbuscular mycorrhizal fungi. Pesquisa Agropecuária Brasileira. 41, 1405-1411.

St-Arnaud, M., Vujanovic, V. 2007. Effect of the arbuscular mycorrhizal symbiosis on plant diseases and pests. In: Hamel, C. \& Plenchette, C. (eds). Mycorrhizae in crop production. Haworth Food \& Agricultural Products Press, Binghampton, NY. pp. 67-122.

Strange, R.N. 2003. Introduction to plant pathology. John Wiley \& Sons Ltd. West Sussex, England. 464 pp.

Tenuta, M., Lazarovits, G. 2002. Identification of specific soil properties that affect the accumulation and toxicity of ammonia to Verticillium dahliae. C. J. Plant Pathol. 24, 219-229.

Tenuta, M., Lazarovits, G. 2004. Soil properties associated with the variable effectiveness of meat and bone meal to kill microsclerotia of Verticillium dahliae. Appl. Soil Ecol. 25, 219-236. 
Toljander, J.F., Lindahl, B.D., Paul, L.R., Elfstrand, M., Finlay, R. 2007. Influence of arbuscular mycorrhizal mycelial exudates on soil bacterial growth and community structure. FEMS Microbiol. Ecol. 61, 295-304.

Trudgill, D.L., Blok, V.C., Bala, G., Daudi, A., Davies, K.G., Gowen, S.R., Fargette, M., Madulu, J.D., Mateille, T., Mwageni, W., Netscher, C., Phillips, M.S., Sawadogo, A., Trivino, C.G., Voyoukallou, E. 2000. The importance of tropical root-knot nematodes (Meloidogyne spp.) and factors affecting the utility of Pasteuria penetrans as a biocontrol agent. Nematology. $823-845$.

Trudgill, D.L. 1990. Resistance to and tolerance of plant parasitic nematodes in plants. Annu. Rev. Phytopathol. 29, 167-192.

Vega, F.E. 2008. Insect pathology and fungal endophytes. J.invertebr.Pathol. 98, 277-279.

Venette, R.C., Mostafa, F.A.M., Ferris, H. 1997. Trophic interactions between bacterial-feeding nematodes in plant rhizospheres and the nematophagous fungus Hirsutella rhossiliensis to suppress Heterodera schachtii. Plant Soil. 191, 213-223.

Veresoglou, S.D., Chen, B., Rillig, M.C. 2012. Arbuscular mycorrhiza and soil nitrogen cycling. Soil Biol.Biochem. 46, 53-62.

Vessey, J.K. 2003. Plant growth promoting rhizobacteria as biofertilizers. Plant Soil. 255, 571-586.

Villalobos, F.J. 1994. The contribution of Melolonthid larvae to soil fertility. Proc. $15^{\text {th }}$ World Congress of Soil Science. Vol. IVd: 129-143.

Villalobos, F.J. 1994a. The role of soil organic matter in the sustainable management of the gress grub Costelytra zealandica (White) in Canterbury pastures. Ph.D. Thesis. Lincoln University, New Zealand. $242 \mathrm{p}$.
Vinale, F., Sivasithamparam, K., Ghisalberti, E.L., Marra, R., Barbetti, M.J., Lim, H., Woo, S.L., Lorito, M. 2008. A novel role for Trichoderma secondary metabolites in the interactions with plants. Physiol. Mol. Plant Pathol. 72, 80-86.

Wang, Y., Shi, Y., Li, B., Shan, C., Ibrahim, M., Jabeen, A., Xie, G., Sun, G. 2012. Phosphate solubilization of Paenibacillus polymyxa and Paenibacillus macerans from mycorrhizal and non-mycorrhizal cucumber plants. Afr. J. Microbiol. Res. 6, 4567-4573.

Welc, M., Ravnskov, S., Kieliszewski-Rokicka, B., Larsen, J. 2010. Suppression of other soil microorganisms by mycelium of arbuscular mycorrhizal fungi in root-free soil. Soil Biol. Biochem. 42, 1534-1540.

Whipps, J.M. 2001. Microbial interactions and biocontrol in the rhizosphere. J. Exp. Bot. 52, 487-511.

Whipps, J.M. 2004. Prospects and limitations for mycorrhizas in biocontrol of root pathogens. Can. J. Bot. 82, 1198-1227.

Widmer, T.L., Mitkowski, N.A., Abawi, G.S. 2002. Soil organic matter and management of plantparasitic nematodes. J. Nematol. 34, 289-295.

Xavier, L.J.C., Germida, J.J. 2003a. Selective interactions between arbuscular mycorrhizal fungi and Rhizobium leguminosarum bv. viceae enhance pea yield and nutrition. Biol.Fert. Soils. $37,261-267$.

Xavier, L.J.C., Germida, J.J. 2003b. Bacteria associated with Glomus clarum spores influence mycorrhizal activity. Soil Biol.Biochem. 35, 471478.

Xu, G., Fan, X., Miller, A.J. 2012. Plant Nitrogen Assimilation and Use Efficiency. Annu. Rev. Plant Biol. 63, 153-182. 
Yeates, G.W., Bongers, T., De Goede, R.G.M., Freckman, D.W., Georgieva, S.S. 1993. Feeding habits in soil nematode families and genera : an outline for soil ecologists. J. Nematol. 25, 315331.

Zasada, I., Avendano, F., Li, Y.C., Logan, T., Melakeberhan, H., Koenning, S.R., Tylka, G. L. 2008. Potential of an alkaline-stabilized biosolid to manage nematodes: case studies on soybean cyst and root-knot nematodes. Plant dis. 92, 4-13.
Zhang, L., Fan, J., Ding, X., He, X., Zhang, F., Feng, G. 2014. Hyphosphere interactions between an arbuscular mycorrhizal fungus and a phosphate solubilizing bacterium promote phytate mineralization in soil. Soil Biol. Biochem. 74, 177-183. 